\title{
The Development of Instructional Video in Drawing Illustration at Fine Arts
}

\author{
Sri Juita Br Ginting \\ Educational Technology, Postgraduate Program \\ State University of Medan \\ Medan, Indonesia \\ srijuita10@gmail.com
}

\author{
Abdul Hamid K \\ Educational Technology, Postgraduate Program \\ State University of Medan \\ Medan, Indonesia
}

\begin{abstract}
The instructional video was developed to teach Senior High School students in drawing illustration at Fine Arts in effective and efficient way independently or collectively in the classroom. This study aims to produce an instructional video in drawing illustration which is decent to be a reference in the learning process of Fine Arts and to validate and assess the effectiveness of the video. This study belongs to a research and development which uses the R\&D model by Borg and Gall and combined with the instructional design model by Dick and Carey. The result of the validation and trial process shows that the developed instructional video is in the criteria of very decent. This result indicates that the media is proper to use in drawing illustration at Fine Arts. The result of hypothesis testing proves that there is a significant difference between the learning outcomes of students who were taught with instructional video and students who were taught with youtube video. Therefore, the instructional video is proper and effective used in drawing illustration at Fine Arts.
\end{abstract}

Keywords- Development; Instructional video; Drawing illustration

\section{INTRODUCTION}

Science and technology is a phenomenon that continues to experience changes and developments today. The development of science and technology is not limited by time and space. These changes directly or indirectly have a considerable influence on several aspects of human life. One aspect of human life that is influenced by changes in science and technology is the aspect of education. As a foundation for the progress of an education nation, it is demanded to be able to adjust to these developments. Education is expected to be able to produce a new generation that has multiple intelligences and continues to develop harmoniously and optimally, possessing relevant and varied knowledge and skills.

In line with the Law of the Republic of Indonesia Number 20 Year 2003 concerning the national education system Chapter II article 3, states that national education aims to develop the potential of students to become people of faith and to be devoted to God Almighty, noble, healthy, knowledgeable , competent, creative, independent and become democratic citizens, and responsible. This shows that education has a very important role in the progress and welfare of a nation.
However, this success cannot be achieved if there is no support from various parties involved and directly participates in the education process.

The learning process has elements that must be considered, where these elements will form a system. Elements included in learning such as objectives, teacher, material, learning activities, media, evaluation and so on. All of these elements form a bond or unity and influence each other. The teacher is one aspect that is very important in shaping the quality of education. How to deliver material, media, methods and strategies used by educators during teaching and learning activities, can influence students in understanding the subject matter delivered.

Learning activities must have a process in accordance with the objectives to be achieved by planning various possibilities to be carried out, as conveyed by Nidawati [8] in her study that learning is a process activity and is a very fundamental element in every type and level of education. This means that the success or failure of achieving educational goals depends on the learning process experienced by students.

This opinion is supported by Sain [9], in his research which approved the study of the process of changing individual research results with their environment. Changes in behavior as a result of continuous learning, Functional, positive, active and directed.

Everyone's learning can be done in different ways. There is learning by seeing, discovering and also imitating. Through learning a person will experience growth and change in him both psychologically and physically. Learning is a combination composed of human elements, material facilities, supplements and procedures that influence each other to achieve learning objectives. For this reason, educators should choose and determine the right instructional strategies and media to achieve these learning goals. As explained by Muhson [7], in his research that media instructional is a vehicle for channeling messages and learning information.

A well-designed instructional media will greatly assist students in digesting and understanding student material. This opinion is in line with research Falahudin [5] which says that instructional media is one of the instructional components that determines learning success. The use of instructional media in the teaching and learning process can arouse new interests and 
desires, arouse motivation and stimulation of learning activities and can also bring psychological influences on students.

The use of instructional media gives a new color in the world of education, the use of media more or less has helped educators in the teaching and learning process, as seen in Adegbija's research [1], which states that the media not only completes the instructional process but also increases the learning enthusiasm of participants students.

Instructional media is used as a tool to channel information from educators to students by stimulating students' thoughts, feelings, concerns and interests so that the learning process becomes more efficient. The benefits and importance of the media are also evident from previous studies which showed an increase in learning outcomes through the use of instructional media, including research by Turyati, Muchtarom, \& Winarno [14], Sokhibul Anshor, and Rahma (2015: 1-9 ), which states that the media has a significant influence on the process and learning outcomes.

Development of science and technology today, teacher professionalism is not enough just to be able to teach students, but also must be able to manage information and the environment to facilitate student learning activities. The concept of the environment includes methods, media, assessment systems, and facilities and infrastructure needed to produce a more efficient and effective learning process. The use of media is expected to overcome communication barriers in the learning process. The development of instructional media should be pursued to take advantage of the advantages possessed by the media and try to avoid obstacles that may arise in the learning process.

In a study conducted by Wiratmoko [15], the problems that exist in school learning, such as students' saturation of the material being taught, the allocation of time and conditions of school facilities, encourage teachers to change the learning process by utilizing digital technology. With the help of the media, the message to be conveyed will be more quickly absorbed and understood by students. Likewise in the process of learning fine arts, in the learning of fine arts the transaction process of messages (information, knowledge, ideas, feelings, skills and so on) through words words, writings, pictures, charts or symbols between the teacher as a communicator and students as communicants or vice versa, this shows that educational media have an important position in the process of learning fine arts.

In fine arts learning, serving with verbal language is less effective as a learning tool, but this does not mean that teaching and learning activities do not need to use words. The benefits of media for the learning of art are not just visual aids but everything that smooths the learning process, so that the material delivered is more easily understood by students, therefore instructional media is a part that should be used and developed by art teachers in the teaching and learning process - As said by Sutiyaso [13] in his research that the use of instructional media in the teaching and learning process, especially in learning arts and culture can arouse interest, student motivation and stimulate learning activities to be more effective.

Art education is one of the easiest media to use in instilling character values in humans. Art education is useful in developing the potential of students, because it can provide aesthetic experiences through creative and appreciative activities. Conceptually, art and culture education (art) in public schools (kindergarten, elementary, junior high, high school) is oriented to the process, namely "education through art" (education through art). This means that arts and culture education is directed to be able to develop all the potential of students, not only in the scope of art technically, but also in its contribution to other subjects. In this case the child is not required to be proficient in art, but in the process the values of creativity, aesthetic sensitivity, and courage of expression are well grown and developed Zulkifly [16].

Culture and art subjects in the education curriculum try to develop a sense of beauty that is useful for students, because through these subjects the ability to create students can be developed. With the existence of arts and culture lessons are expected to help students in developing thinking, creativity, taste and be able to arouse students' intention. As revealed by Suhaya [12] in his research that art education can be a forum or a means for students to express and develop their creativity.

There are four types or fields in art learning, namely art, music, dance and drama. Where this research is focused on art education, especially on drawing illustration material. Fine art learning is a learning activity that focuses on imaging objects that are created, shown and appreciated, students are expected to understand conceptually and conceptually. Through art lessons students engage in experience to develop personal expressions, aesthetic considerations and critical awareness.

Hakim [6] in the Procurement of International Seminar on Languages and Arts (ISLA), stated that teachers still had difficulty in implementing art learning. These basic obstacles include mastery of the material, designing learning activities and utilizing and developing instructional media needed in fine arts learning.

The selection of learning methods carried out by fine arts teachers generally uses lecture, demonstration and practice methods. The lecture method is used by the teacher when delivering the material, while the demonstration, is carried out by the teacher when doing the practice, because the ongoing learning process emphasizes the ear training strategy, so when the practice takes place students depend on the examples made by the teacher through the demonstration method, this is very inefficient considering the limited time allocation.

These problems are also evident from the results of the writer's observation, in organizing learning of art and culture subjects at SMA Negeri 1 Berastagi there are obstacles faced by the teacher, among others: Interest in learning art and culture students are still very low, learning materials or materials are still limited, because teachers have difficulty finding suitable media for visual arts learning especially drawing illustrations, as well as limited time and space. Based on interviews with some students about fine arts, most students think that good art is realist art which is limited to 
drawing humans, animals and plants, so many students find art difficult. From the observation it was also found that students who lack talent in learning art have low interests, because it is indoctrinated by the opinion that art is only limited to those who have talent.

Apart from these obstacles, there were other problems found in the learning process, which during this time the learning process carried out was still conventional. When the visual arts teacher's practice activities that I met had tried as much as possible in carrying out learning by using teaching materials in the form of pictures and examples of illustrated works, but students still had difficulty in drafting ideas or ideas and pouring them into work, especially in the process making of this illustration. There are no guidelines that can be followed by students, it is certain that students will have difficulty completing the practical assignment. In addition, the different abilities of each student also become one of the serious obstacles, when the teacher practices the process of drawing illustrations directly on writing in the classroom, not all students can apply them well, and of course the process cannot be repeated. reset. Therefore teachers are expected to use more efficient media that can help students in the process of drawing illustrations.

Judging from the facilities in Berastagi 1 public high school, it is sufficient to support the use of media in the learning process. Berastagi 1 Public High School has been facilitated by In Focus in several classrooms, besides the average students of Berastagi 1 Public High School have laptops that can be used in daily learning activities, but if observed, teachers are still less than optimal in utilizing these facilities, even more so in the study of art. Learning art is related to the ability to put ideas into concepts which are then formed in a work. To produce an interesting concept or idea requires direct observation from various references. Students must be triggered to increase their creativity, as well as stimuli to motivate interest in work, so the teacher needs to compile a media by utilizing these facilities.

In art learning, there are some teachers who are not competent in their fields, teachers in the field of arts and culture studies may come from music, dance or fine art teachers because in their learning, fine arts, music and dance are integrated into the subjects of art and culture. Therefore, teachers often have difficulty in delivering material, especially in art lessons if the teacher does not come from an art education program. Fine art is an abstract learning material, each person can have different responses and opinions on a concept in art, so that media is needed that can facilitate teachers in delivering art subject matter, even though the educator is not from an art education background, and helps students to arrange the abstract concept to be more real.

Based on these problems the author wants to develop a instructional media in the form of instructional videos. Using video media is a simple way of integrating technology into the classroom. Video media has attributes as a moving picture media or motion pictures. This media has the ability to display elements of sound (audio) and images (visual) simultaneously in the form of moving images or moving images with a high degree of clarity. Instructional videos are considered to make it easier for students to understand the material delivered by the teacher in the teaching and learning process in the classroom. Students today are always connected with technology media, especially television, therefore the use of video media in the teaching and learning process will attract students' interest, because students are familiar with the video media. Besides that video can also be used as a instructional media independently by students, this is because video programs can be integrated into hardware or hardware that is portable, allowing video users to use it anywhere.

The use of video media is considered effective because video can also be used for almost all topics, types of learning, and every domain: affective, psychomotor and interpersonal, as explained by Busyaeri, Tamsik and Zaenuddin [3]. In the effective realm, videos can strengthen students in feeling the emotional and attitude aspects of effective learning. In the psychomotor domain, video has the advantage of showing how things work. Instructional videos provide opportunities for students to observe and evaluate subject matter and can be repeated. Whereas in the realm of increasing interpersonal competence, videos provide opportunities for students to discuss what they have watched together, students can observe and analyze each other before watching a video.

There are many advantages to video media when it is used as a learning medium, the duration of an adjustable learning video is able to provide more flexibility for the teacher and can direct learning directly to the needs of students. Other advantages as stated by Rusman include (1) Video can give messages that can be received more evenly by students, (2) Video is very good explaining a process, of course this is very supportive in learning fine arts especially drawing illustrations, where in drawing illustrations the most important thing to be understood by students is the process of forming each element in drawing illustrations to form a complete work. (3) Overcoming the limitations of space and time, more realistic and can be repeated or stopped as needed, and (4) Give a deep impression, which can affect student attitudes.

Based on the description above, the researcher is interested in conducting research and development of video-based instructional media in illustrative drawing instruction. Through the instructional video media developed in this study, it is hoped that it can stimulate students to learn more creatively, independently and have high motivation in improving their drawing skills illustration

\section{METHOD}

This development research will be carried out at Berastagi 1 High School (SMA) located at Jalan Jamin Ginting No.1 Berastagi. The study was conducted in the odd semester of the 2018/2019 study year, the research was conducted in July 2018 to November 2018. The study began with a review of the research location to find out carefully about the number of classes and conditions of class XI students, background, teacher abilities, facilities study and classroom conditions.

The development model is a series of procedures in order to produce instructional media drawing illustrations. The 
model developed refers to the Research and Development (R\&D) adaptation of the Borg \& Gall [2] model combined with the model of instructional development model Dick and Carey [4].

The trial design of this instructional video media will have several stages, namely: (1) validation of material experts in fine arts subjects, (2) validation of media construction, (3) development revision (stage I), based on an assessment in the form of input, criticism or advice from experts, material, and media construction, (5) small group trials by 9 students, (6) phase II revisions, based on assessments in the form of input, criticism or suggestions from small group trials, (7) tests field trials of 15-30 students about the assessment of the attractiveness and feasibility of the product, (8) revision stage III, based on assessments in the form of input, criticism or suggestions from field trials, (9) improvement of the final product interactive learning media, and continued by testing the effectiveness of the product in the learning process.

Analysis of the data in this study used quantitative descriptive analysis. All data will be analyzed with descriptive statistical techniques that are quantitatively separated by categories to sharpen the judgment in drawing conclusions.

The steps of data analysis technique are as follows: average value, standard deviation, normality test, homogeneity test. To see the value of the effectiveness of the instructional media being experimented with use the following formula for calculating effectiveness (Sugiyono, 2007):

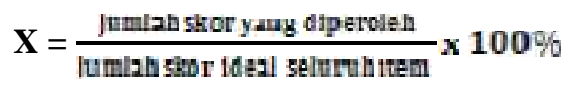

With the evaluation criteria as written in table 1 below:

TABLE I. ASSESSMENT CRITERIA

\begin{tabular}{|c|l|c|}
\hline No & \multicolumn{1}{|c|}{ Kategori } & Rentang skor \\
\hline 1 & Very Good & $86 \% \leq \mathrm{X} \leq 100 \%$ \\
\hline 2 & Good & $76 \% \leq \mathrm{X}<85 \%$ \\
\hline 3 & Poor & $66 \% \leq \mathrm{X}<75 \%$ \\
\hline 4 & Not Good & $56 \% \leq \mathrm{X}<65 \%$ \\
\hline 5 & Very Poor & $0 \% \leq \mathrm{X}<55 \%$ \\
\hline
\end{tabular}

$\mathrm{X}=$ Empirical Score

\section{RESULT AND DISCUSSION}

\section{A. Product development results}

The development of instructional video drawing illustrative media products is carried out in reference to the Borg \& Gall development research model and combined with the steps of developing Dick \& Carey's learning material. Development of instructional video media for drawing illustrations is done based on the stages as contained in the procedure. The results of the subsequent development are carried out due diligence or validation by experts who have been determined. Based on the results of the validation carried out, the instructional video drawing media product was declared to be feasible to be continued in the field trials.
The product development research conducted was directed to produce a product in the form of instructional video media to draw illustrations in class XI of high school that is used to improve the instructional process and student competence. Revised and refined aspects based on data analysis and trials and input from material experts, instructional video media experts. It aims to explore some aspects that are common in the process of developing a product. The aspects of instructional video media assessed include aspects of information guidance, software operations, systematics, aesthetics, and media principles.

Some of the uses and benefits in the use of instructional drawing instructional video media are as follows: (1) instructional video media can solve problems because the concepts are planned to facilitate students and systematically, (2) instructional video media illustrative gives students the opportunity to learn according to the power of thought of each individual, (3) learning faster and more interesting so it does not cause boredom, (4) instructional media video drawing illustration can also be used as an alternative to conventional and individual instructional video media, overcoming distance and time, able to draw by using the steps in instruction, can be repeated if necessary to add clarity, the message is delivered quickly, and easy to remember and able to act as the main media to solve problems that will be discussed in class.

\section{B. Research Results Product Feasibility Test}

Based on the results of the validation conducted, instructional drawing video media product was declared to be suitable for use in learning media. The instructional drawing video media developed has met the standards based on the design of the development of instructional video media development standards and learning material standards. The results of product eligibility can be seen in table 2 below:

\section{TABLE II. SUMMARY OF PRODUCT FEASIBILITY RESULTS VALIDATED BY EXPERTS AND TRIALS}

\begin{tabular}{|c|l|c|c|}
\hline No & Indicator & $\begin{array}{c}\text { Percentage } \\
\text { Average }\end{array}$ & Criteria \\
\hline 1 & $\begin{array}{l}\text { Material } \\
\text { expert }\end{array}$ & $92,67 \%$ & $\begin{array}{c}\text { Very } \\
\text { Proper }\end{array}$ \\
\hline 2 & Media expert & $91,66 \%$ & $\begin{array}{c}\text { Very } \\
\text { Proper }\end{array}$ \\
\hline 3 & $\begin{array}{l}\text { Small group } \\
\text { trials }\end{array}$ & $93,17 \%$ & $\begin{array}{c}\text { Very } \\
\text { Proper }\end{array}$ \\
\hline 4 & Field trials & $94,19 \%$ & $\begin{array}{c}\text { Very } \\
\text { Proper }\end{array}$ \\
\hline \multicolumn{2}{|c|}{ Average } & $\mathbf{9 2 , 9 2 \%}$ & $\begin{array}{c}\text { Very } \\
\text { Proper }\end{array}$ \\
\hline
\end{tabular}

The results of the questionnaire that was submitted to the material experts gave a response of $92.67 \%$ that the instructioanl video media was appropriate because it contained material and delivery criteria that met the requirements for delivering messages to students. Media experts gave a response of $91.66 \%$ that the instructional drawing video media was appropriate because it had fulfilled the principles and 
criteria for the development of instructional video media. The results of small group trials gave $93.17 \%$ responses that the instructional video drawing illustration was suitable for use. The results of the field trials gave a response of $94.19 \%$ that the learning video drawing illustration media was appropriate for use in instructional.

Based on the results of validation and testing, the instructional video drawing illustration media is very appropriate to be used in the process of instructional to draw illustrations, with the instructional video media drawing illustrations the learning process can be carried out effectively.

\section{Discussion of Research Results}

This research and development is carried out aimed at producing products in the form of instructional video media to draw decorative illustrations that are feasible and effectively used. In this research and development, several stages are carried out to produce appropriate and effective instructional video media products, among others, needs analysis, collection of material / subject matter that is in accordance with student characteristics, designing scripts and storyboards that serve as a reference for making instructional video media, validation by material experts and media construction experts, conducting data analysis and product revisions.

The development of instructional video media for drawing illustrations in this study was arranged in sequence according to their sequences, starting from the instructions, core competencies, basic competencies, indicators, learning objectives, summary material, exercises and profiles of instructional video media developers. Core competencies, basic competencies, indicators, learning objectives are made aiming that students understand what competency must be achieved after learning the material to draw decorative illustrations. In the material section, the material about (1) understanding, elements, rules and principles of drawing illustrations, (2) basics, types and main elements in drawing illustrations, (3) techniques, concepts and procedures for drawing illustrations, and accompanied video tutorial drawing decorative illustrations.

Based on this, students can gain an understanding of concepts and theories that can later be applied to the practice of drawing illustrations. Each section of material is made separately and is accompanied by a hint icon, home, and start page to make it easy for users to access the desired material section. In addition, each display of material is accompanied by animation and decorative illustration images that can be used by students as a reference to develop their creativity and imagination.

Instructional video media for drawing illustrations is declared feasible and effective to use, this can be seen from the results of the average value of drawing illustrations taught with instructional video media that is equal to $90.95 \%$. While the results of learning to draw illustrations taught by using conventional media is $83.57 \%$. This proves that the use of instructional video media is more feasible and effective in increasing students' competence and knowledge instruction to draw illustrations than using conventional videos.

\section{CONCLUSION}

Based on the results of research, development and discussion previously stated, it can be concluded

- Products in the form of instructional video drawing illustration in fine art subjects in class XI of SMA Negeri 1 Berastagi have results that are worthy of being the final product that can be disseminated and implemented to users. This is made clear by several stages, namely validation to material experts, media experts, small group trials and field trials. All assessment results obtained at that stage obtained a total score of $92.92 \%$ included in the "very feasible" category.

- Based on the results of data processing the average value of student Instructional video media for drawing illustrations with student learning outcomes using conventional media shows that students who use Instructional video media for drawing illustrations "more effective" than students who use conventional media.

\section{References}

[1] Adegbija, M. V., \& Fakomogbon, M. A. (2012). Instructional Media In Teaching and Learning: A Nigerian Perspective. Global Media Journal African Edition, 6(3). 216-230. ISSN. 2073-2740.

[2] Borg, W. R., \& Gall, M. D. (1983). Educational Research: An Introduction. New York: Longman.

[3] Busyaeri, A., Tamsik, U., \& Zaenuddin, A. (2016). Pengaruh Penggunaan Video Pembelajaran Terhadap Peningkatan Hasil Belajar Mapel IPA di MIN Kroya Cirebon. Jurnal Al Ibtida: Jurnal Pendidikan Guru Mi, 3(2). 116-137. ISSN: 2442-5133.

[4] Dick, W., \& Carey, L. (2005). Systematic Design Of Instructional (5th Ed). New York: Addison - Wesley Education Publisher Educational Technology Publicational, Inc.

[5] Falahudin, I. (2014). Pemanfaatan Media Dalam Pembelajaran. Jurnal Lingkar Widyaiswara, 1(4). 104-117. ISSN : 2355-4118.

[6] Hakim, R. (2012). Pembelajaran Seni Budaya di Era Global (Sebuah Tantangan Baru yang Dihadapi oleh Pendidik Seni). Procceding of International Seminar on Languages and Arts (ISLA), 1(1). 296-299. ISBN : 978-602-17017-2-0b

[7] Muhson, A. (2010). Pengembangan Media Pembelajaran Berbasis Teknologi Informasi. Jurnal Pendidikan Akuntansi Indonesia, 8(2). 1-10. ISSN: 0853-9472

[8] Nidawati. (2013). Belajar Dalam Perspektif Psikologi dan Agama. Jurnal Pionir, 1(1). 13-28. ISSN: 2088-286.

[9] Sain, M. H. (2014). Konsep Belajar dan Pembelajaran. Jurnal Lentera Pendidikan,17(1). 66-79. ISSN: 1979-3472.

[10] Sugiyono. (2011). Metode Penelitian Kuantitatif Kualitatif Dan R\&D. Bandung. Alfabeta.

[11] Suhaya. (2016). Pendidikan Seni Sebagai Penunjang Kreatifitas. Jurnal Pendidikan dan Kajian Seni, 1(1). 1-15. ISSN 2503-4626.

[12] Sutiyaso. (2017). Pengelolaan Pelaksanaan Pembelajaran Seni Budaya di SMA Negeri 1 Pulokulon Grobogan. Universitas Muhammadiyah Surakarta.

[13] Turyati, M. Muchtarom, \& Winarno. (2016). Pengaruh Penggunaan Media Video Edukasi Terhadap Hasil Belajar Pkn Siswa Kelas VII SMP Negeri 2 Gondangrejo. Jurnal Pkn Progresif, 11(2). 256-267.ISSN: 1907-5332.

[14] Wiratmoko, C. (2017). Digitalisasi Pembelajaran Seni Budaya: Pembelajaran Motif Batik di SMA Negeri 2 Surabaya. Seminar Nasional Seni dan Desain: 407-416. ISSN. 2541-6626.

Zulkifly. (2016). Strategi Pembelajaran Seni Budaya Di Sekolah (Seni Rupa Dalam Materi Seni Budaya). Diakses 5 Feberuari 2018 Melalui Http://Digilib.Unimed.Ac.Id/915/2/Full\%20text.Pdf 
